\title{
Social presence and motivation in online environments: Second Life versus the Enocta Learning Management System/Adobe Connect
}

\author{
Mesut Ozonur \\ Cukurova University, Turkey \\ Tugba Yanpar-Yelken, \\ Mersin University, Turkey \\ Hatice Sancar-Tokmak \\ Mersin University, Turkey
}

\begin{abstract}
This study aims to compare the social presence and motivation of students taking a database II course using either the virtual world Second Life (SL) or the Enocta learning management system (LMS)/Adobe Connect. The study group consisted of 60 undergraduate sophomore students enrolled in a fully online computer programming program. Students were divided into two groups of 30. The first group was the experimental group taking the course on Second Life and the latter was control group taking the course through the Enocta LMS/Adobe Connect. A matching-only pre- and post-test control group design was applied. The data were collected through the Perceived Sociability Scale of Computer-Supported Collaborative Learning Environments (Sociability Scale) and the Motivated Strategies for Learning Questionnaire (MSLQ). The results of the study showed significant differences in motivation and social presence scores in favour of the students taking the course through Second Life.
\end{abstract}

\section{Introduction}

The world's population is increasing, and global information practices are changing rapidly. In parallel, the educational needs of people are growing and diversifying, making distance education a popular choice. As Lou (2004) stated, since online instruction offers such flexible options, educational institutions offer those courses to enhance the quality of education for large populations and to meet the life-long learning demands of contemporary society. Özkul and Aydın (2013) stated that distance education is a necessity for developing countries because of their huge student populations, limited educational institutions, and infrastructure problems.

Web-based education is one of the most beneficial modern distance models offered through the Internet or intranets (Al \& Madran, 2004). Hannum (2008) observed that web-based education can be synchronous or asynchronous. As advocated by Karaş and Kahraman (2011), these options provide advantages in terms of cost, time-setting, and technology. However, web-based education also has disadvantages in terms of socialisation, interaction, and group work, and it is not suitable for students who cannot manage their own learning (Odabaş, 2003). Sancar-Tokmak, Baturay, and Fadde (2013) found that students in a web-based online master's program expressed that their program should be revised in terms of course content, interaction, and assessment. All these issues are related to course quality and they affect dropout rates (Willging \& Johnson, 2004). Issues related to course quality also have an influence on student satisfaction, which is also related to social presence (Bulu, 2011). Interaction is a key term in distance education (Keegan, 1980), and deficiencies in interaction can negatively affect learner social presence and motivation (Khan, 2011; Lu, Huang, Ma, \& Luce, 2007).

Virtual reality environments such as Second Life (SL) provide opportunities for collaboration, dialogue, and interaction between distance education learners (Bowers, 2010; Collins, 2012; Khan, 2011; Macedo \& Morgado, 2009; Omale, 2010; Palomaki, 2009; Zhang, 2009). Each of these elements is a component of social presence (Streur, 1992) and study motivation (Collins; 2012; Ma, Oikonomou, \& Zheng, 2009). There are very few empirical studies investigating social presence and motivation between students using different online learning environments. For this reason, the current study aims to investigate differences in social presence and motivation scores between students taking a course through SL and through the Enocta learning management system (LMS)/Adobe Connect (web-based education) when instructional strategies 
are identical for both groups of students. This study will contribute to the literature by providing empirical results regarding whether SL supports social presence and motivation in learners. In accordance with the purpose of this research, the following research questions have been addressed:

1. Is there any significant difference in terms of social presence scores between students taking a database course through SL or through the Enocta LMS/Adobe Connect?

2. Is there any significant difference in terms of motivation scores between students taking a database course through SL or through the Enocta LMS/Adobe Connect?

\section{Social presence and motivation in SL learning environments}

Social presence and motivation are two key factors affecting learner satisfaction and dropout rates in distance education. Garrison (2007) described social presence as:

[T]he ability to project one's self and establish personal and purposeful relationships. The three main aspects of social presence, as defined here, are effective communication, open communication and group cohesion. (p. 63)

Ahl (2006) presented different descriptions of motivation and concluded:

These definitions conceptualize motivation either as dispositions, as energy and direction, as something instigated by goals, as based in needs, or as a process governing choices. (p. 3)

Mennecke et al. (2008) advocated that 3D worlds offer important opportunities for socialisation, social networking, entertainment, collaboration, and business. Moreover, scholars such as Bell (2009), Macedo and Morgado (2009), Wang and Braman (2009), Wang and Shao (2012), and Warburton (2009) demonstrated that SL can support learners' socialisation and motivation. Mayrath, Traphagan, Heikes, and Trivedi (2011) describe SL as "simply a virtual world that provides a platform for users or avatars to create and/or explore places and spaces.” (p. 126) by emphasising that tools in SL environments allow more creative and flexible instructional designs.

Many research studies found out that, as a learning environment, SL supports learners' presence and belonging. Bulu (2011) investigated the relationships between three types of presence in virtual worlds as well as their relationship with satisfaction and immersive tendencies. Data was collected through a subjective questionnaire that showed a significant relationship among place presence, social presence, and co-presence. While all types of presence affected satisfaction, social presence affected it most. Edirisingha, Nie, Pluciennik, and Young (2009) investigated how learning activities can facilitate social presence, foster socialisation, and promote collaborative learning among distance learners in SL. Two instructors and four students attended to learning activities on the University of Leicester (UoL) Media Zoo island in SL. Data collected through interviews, observations, and chat logs showed that students' access and motivation, socialisation, and role identity progressed due to the use of avatars. Meanwhile, Omale, Hung, Luetkehans, and Cooke-Plagwitz (2009) investigated the effects of 3D world attributes on participants' social, cognitive, and teaching presences. According to study results, 3D technology enhanced participants' social presence but not cognitive or teaching presence (Omale et al., 2009). Khan's (2011) study examined two higher education instructors teaching online in SL and how they thought about and applied social presence strategies during instruction. Results showed social presence was enhanced in SL, but to achieve this faculty development and institutional support were a necessity (Khan, 2011). Vrellis, Avouris, and Mikropoulos (2016) compared real world and virtual world groups' learning outcomes, satisfaction, and presence during the implementation of laboratory problem-based learning (PBL) activity. According to the results, both the virtual world and real world groups' satisfaction and presence scores were high. There was also a positive correlation between presence and satisfaction (Vrellis, Avouris, \& Mikropoulos, 2016).

According to Keskitalo, Pyykkö, and Ruokamo (2011), SL has the potential to enhance motivation due to features such as avatars, synchronous communication tools, and shared places. In a case study, they applied the Global Virtual Education model on the Global Virtual Collaboration Project (GVCP) course offered through SL and found that the course supported meaningful learning for their 54 student participants (Keskitalo et al., 2011). Moreover, the data analysis showed that students were highly motivated and expressed studying with SL was fun (Keskitalo et al., 2011). According to research conducted by Ma et al., 
(2009), 27 first year students attending a computer games modeling and animation course offered through SL found the environment to be a motivational learning tool. Similarly, Balcikanl1 (2012) investigated the experiences of seven American students learning Turkish as a foreign language and eight Turkish students learning English as a foreign language on SL. In interviews, both groups stated that SL provided authentic interactions and increased their motivation to use the target language as a result of cultural curiosity (Balcıkanl1, 2012). Finally, Çukurbaşı, Bezir, and Karamete's (2011) study explored the perceptions of 30 computer education and instructional technology students about an orientation program offered through SL and found that the program was motivational and fun.

\section{Method}

This study used a quasi-experimental, matching-only pre- and post-test control group design (Fraenkel \& Wallen, 2000). In this research design, participants are at first matched and then assigned to an experimental or control group in order to prevent validity problems stemming from variable differences. The schema of the research method is shown in Table 1.

Table 1

Schema of research methods

\begin{tabular}{cccccc}
\hline $\mathrm{G}_{1}$ & $\mathrm{M}$ & $\mathrm{O}_{1.1}$ & Orientation & $\mathrm{X}$ & $\mathrm{O}_{1.2}$ \\
$\mathrm{G}_{2}$ & $\mathrm{M}$ & $\mathrm{O}_{2.1}$ & & & $\mathrm{O}_{2.2}$ \\
\hline
\end{tabular}

$\mathrm{G}_{1}$ (Group 1: experimental group)

$\mathrm{G}_{2}$ (Group 2: control group

$\mathrm{M}$ (Matching)

$\mathrm{O}_{1.1}, \mathrm{O}_{2.1}$ (Observation 1 for both groups)

$\mathrm{X}$ (Intervention)

$\mathrm{O}_{1.2}, \mathrm{O}_{2.2}$ (Observation 2 for both groups)

Students in both the experimental and control groups were enrolled in the BPP 211 Database II course through distance education. The same instruction was applied to both groups, but the environments were different. The control group took the course through the Enocta LMS/Adobe Connect, while the experimental group took the same course through SL. In this study, the dependent variables were social presence and motivation, while the independent variable was the learning environment.

\section{Sampling}

The participants were 60 distance education students from the Vocational School of Higher Education Computer Programming program enrolled in the BPP 211 Database course. Participants were assigned to experimental and control groups as a result of a matching procedure applied. The experimental group consisted of 30 students, 8 females and 22 males, who took the course through SL. The mean age was 26.25 years. The control group consisted of 30 students, 5 females and 25 males, who took the course through the Enocta LMS/Adobe Connect. The mean age was 28.2 years.

\section{Instruments}

During the study, three instruments were administered: a demographic questionnaire, the Perceived Sociability Scale of Computer-Supported Collaborative Learning Environments (Sociability Scale), and the Motivated Strategies for Learning Questionnaire (MSLQ).

\section{Demographic questionnaire}

This questionnaire was prepared by the researchers and checked by two experts in distance education and educational technology. It included questions related to gender, computer ownership, 3D environment capabilities of computers owned, Internet access, Internet connection speed, Internet usage frequency, and Internet usage aims.

The Sociability Scale

The Sociability Scale was developed by Kreijns, Kirschner, Jochems, and Van Buuren (2007) to define students' perceived sociability levels in computer-supported collaborative learning environments. The 10item scale has one dimension and a 5-point Likert scale ( $1=$ strongly disagree to $5=$ strongly agree $)$. 
Possible scores range from 10 to 50. In their research, the scale was applied to 93 undergraduate students at the Open University in the Netherlands. Through exploratory factor analysis the Cronbach's alpha coefficient was found to be 0.92 . The scale was translated into Turkish and adapted for online learning environments by Bardakçı (2010). During adaptation, the scale was administered to 94 students taking courses through online learning environments. Through exploratory and confirmatory factor analysis, the Cronbach's alpha coefficient was found to be 0.91 . The adapted version of the scale had 10 items with a 5point Likert scale $(1=$ strongly disagree to $5=$ strongly agree $)$.

\section{MSLQ}

The MSLQ was developed by Pitrinch, Smith, Garcia, and McKeachie (1991 as cited in Büyüköztürk, Akgün, Özkahveci, \& Demirel, 2004). The original questionnaire has two scales, motivation and learning strategies. The current study used the motivation scale, which has six dimensions: intrinsic goal orientation, extrinsic goal orientation, task value, control of learning beliefs, self-efficacy for learning and performance, and test anxiety. The scale has 31 items with a 7-point Likert scale $(1=$ not at all true of me to 7 = very true of me). The original scale was applied to a sample of 380 students at a public, 4-year university in the Midwest. Confirmatory factor analysis was conducted twice, and the Cronbach's alpha coefficient for each dimension of the motivation scale was found to be between 0.62 and 0.93 (Duncan \& McKeachie, 2005, as cited in Artino, 2005).

The scale was translated into Turkish and adapted by Büyüköztürk, Akgün, Özkahveci, and Demirel (2004). It was applied to 852 university students (600 females and 208 males) during the adaptation study, in which expert opinion was taken and exploratory and confirmatory factor analysis were conducted (Büyüköztürk, Akgün, Özkahveci, \& Demirel, 2004). Cronbach's alpha coefficients were found to be between 0.52 and 0.86 .

\section{Procedure}

Table 2 shows the applied instruments and environments for both groups. Participants were assigned to the experimental and control according to their academic success test results. The Sociability Scale and MSLQ was applied as pre- and post-test to both groups. Orientation in SL was only conducted with the experimental group. Moreover, the same instruction was given to both groups. The procedure included five steps: matching, pre-test, orientation, instruction, and post-test.

Table 2

Applied instruments and environments for experimental and control groups

\begin{tabular}{|c|c|c|c|c|c|}
\hline Groups & Matching & Pre-tests & Orientation & $\begin{array}{l}\text { Instruction } \\
\text { and learning } \\
\text { environments }\end{array}$ & Post-tests \\
\hline Experimental & $\begin{array}{l}\text { Academic } \\
\text { success }\end{array}$ & $\begin{array}{l}\checkmark \text { Sociability } \\
\text { Scale } \\
\checkmark \text { MSLQ }\end{array}$ & $\begin{array}{l}\checkmark \text { Downloading/settin } \\
\text { g up Second Life } \\
\text { Viewer" software } \\
\checkmark \text { Second Life } \\
\text { membership } \\
\checkmark \text { Avatar creation } \\
\checkmark \text { Learning } \\
\text { Environment } \\
\text { designed in Second } \\
\text { Life } \\
\checkmark \text { Second Life guide }\end{array}$ & $\begin{array}{l}\text { Second life } \\
\text { environment }\end{array}$ & $\begin{array}{l}\checkmark \text { Sociability } \\
\text { Scale } \\
\checkmark \text { MSLQ }\end{array}$ \\
\hline Control & $\begin{array}{l}\text { Academic } \\
\text { success }\end{array}$ & $\begin{array}{l}\checkmark \text { Sociability } \\
\text { Scale } \\
\checkmark \text { MSLQ } \\
\end{array}$ & & $\begin{array}{l}\text { Enocta } \\
\text { LMS/Adobe } \\
\text { Connect }\end{array}$ & $\begin{array}{l}\checkmark \text { Sociability } \\
\text { Scale } \\
\checkmark \text { MSLQ } \\
\end{array}$ \\
\hline
\end{tabular}

\section{Matching}

Matching was applied to assign participants to the experimental and control groups according to academic success. Gender and age were considered in order to determine similar group participants so individual characteristics would not affect the study results. 
Pre-tests

Two instruments were administered to both groups at the beginning of the study, as well as a demographic questionnaire: the Sociability Scale and the MSLQ. The pre-tests were analysed before instruction to ensure the experimental and control groups were equal in terms of motivation and social presence scores. According to the Kolmogorov-Smirnov test, the normality assumption was not violated. Therefore, the equality of the two groups was analysed through an independent samples $t$-test: a parametric test. Since the $p$ value was greater than 0.05 , the experimental and control group participants were considered equal in terms of social presence and motivation scores at the beginning of the study.

\section{Orientation}

The experimental group attended a 4-week orientation program before the semester. First participants downloaded and set up the SL viewer software from the SL website. Participants then created accounts and personalised avatars with help from the instructor. The SL learning environment was introduced via a group meeting and island tour (island is the term used to describe land acquired in SL).

\section{Instruction and learning environments}

The topics presented, instruction applied, and materials used were the same for both groups (Table 3). The topics were presented over 14 weeks through direct instruction, question-answer strategies, discussion, and hands-on computer practice for both groups. Materials included 14 weekly PowerPoint presentations, extra sources, student notes, and homework assignments. The PowerPoint presentations were prepared by one of the researchers (also the course instructor) and checked by experts on distance education before being uploaded to the class presentation boards in SL or on Adobe Connect. Instruction sessions occurred synchronously with the same instructor for both experimental and control groups.

Table 3

Course topics, session lengths, instruction methods, and materials

\begin{tabular}{|c|c|c|c|c|}
\hline Week & Topics & Session length & Instruction applied & Materials used \\
\hline Week 1 & Basic concepts & 180 minutes & $\begin{array}{l}\text { Direct instruction question- } \\
\text { answering discussion }\end{array}$ & $\begin{array}{l}\text { PowerPoint } \\
\text { presentation } 1\end{array}$ \\
\hline Week 2 & $\begin{array}{l}\text { Entity- } \\
\text { relationship } \\
\text { model }\end{array}$ & 180 minutes & $\begin{array}{l}\text { Direct instruction question- } \\
\text { answering discussion }\end{array}$ & $\begin{array}{l}\text { PowerPoint } \\
\text { presentation } 2\end{array}$ \\
\hline Week 3 & $\begin{array}{l}\text { Relational } \\
\text { Database }\end{array}$ & 180 minutes & $\begin{array}{l}\text { Direct instruction question- } \\
\text { answering discussion }\end{array}$ & $\begin{array}{l}\text { PowerPoint } \\
\text { presentation } 3\end{array}$ \\
\hline Week 4 & Normalisation & 180 minutes & $\begin{array}{l}\text { Direct instruction question- } \\
\text { answering discussion } \\
\text { Demonstration }\end{array}$ & $\begin{array}{l}\text { PowerPoint } \\
\text { presentation } 4\end{array}$ \\
\hline Week 5 & $\begin{array}{l}\text { Relational } \\
\text { algebra }\end{array}$ & 180 minutes & $\begin{array}{l}\text { Direct instruction question- } \\
\text { answering discussion }\end{array}$ & $\begin{array}{l}\text { PowerPoint } \\
\text { presentation } 5\end{array}$ \\
\hline Week 6 & SQL & 180 minutes & $\begin{array}{l}\text { Direct instruction question- } \\
\text { answering discussion }\end{array}$ & $\begin{array}{l}\text { PowerPoint } \\
\text { presentation } 6\end{array}$ \\
\hline Week 7 & $\begin{array}{l}\text { Basic SQL } \\
\text { procedures }\end{array}$ & 180 minutes & $\begin{array}{l}\text { Direct instruction question- } \\
\text { answering discussion } \\
\text { Demonstration } \\
\text { Group work }\end{array}$ & $\begin{array}{l}\text { PowerPoint } \\
\text { presentation } 7\end{array}$ \\
\hline Week 8 & $\begin{array}{l}\text { Basic SQL } \\
\text { functions }\end{array}$ & 180 minutes & $\begin{array}{l}\text { Direct instruction question- } \\
\text { answering discussion } \\
\text { Practicing on computer } \\
\text { Droup work }\end{array}$ & $\begin{array}{l}\text { PowerPoint } \\
\text { presentation } 8\end{array}$ \\
\hline Week 9 & $\begin{array}{l}\text { SQL Multi-Row } \\
\text { Functions }\end{array}$ & 180 minutes & $\begin{array}{l}\text { Direct instruction question- } \\
\text { answering discussion } \\
\text { Demonstration } \\
\text { Group work }\end{array}$ & $\begin{array}{l}\text { PowerPoint } \\
\text { presentation } 9\end{array}$ \\
\hline Week 10 & $\begin{array}{l}\text { Basic joins in } \\
\text { tables }\end{array}$ & 180 minutes & $\begin{array}{l}\text { Direct instruction question- } \\
\text { answering discussion } \\
\text { Demonstration } \\
\text { Group work }\end{array}$ & $\begin{array}{l}\text { PowerPoint } \\
\text { presentation } 10\end{array}$ \\
\hline
\end{tabular}




\begin{tabular}{|l|l|l|l|l|}
\hline Week 11 & $\begin{array}{l}\text { Other joins in } \\
\text { tables }\end{array}$ & 180 minutes & $\begin{array}{l}\text { Direct instruction question- } \\
\text { answering discussion } \\
\text { Demonstration } \\
\text { Group work }\end{array}$ & $\begin{array}{l}\text { PowerPoint } \\
\text { presentation } 11\end{array}$ \\
\hline Week 12 & Subqueries & 180 minutes & $\begin{array}{l}\text { Direct instruction question- } \\
\text { answering discussion } \\
\text { Demonstration } \\
\text { Group work }\end{array}$ & $\begin{array}{l}\text { PowerPoint } \\
\text { presentation } 12\end{array}$ \\
\hline Week 13 & $\begin{array}{l}\text { Data definition } \\
\text { language }\end{array}$ & 180 minutes & $\begin{array}{l}\text { Direct instruction question- } \\
\text { answering discussion } \\
\text { Demonstration } \\
\text { Group work }\end{array}$ & $\begin{array}{l}\text { PowerPoint } \\
\text { presentation } 13\end{array}$ \\
\hline Week 14 & Database objects & 180 minutes & $\begin{array}{l}\text { Direct instruction question- } \\
\text { answering discussion }\end{array}$ & $\begin{array}{l}\text { PowerPoint } \\
\text { presentation } 14\end{array}$ \\
\hline
\end{tabular}

The only difference between the two groups was the learning environment: the experimental group attended the course through SL, while the control group took the same course through the Enocta LMS/Adobe Connect. The SL learning environment was created collaboratively by a designer and the researchers. First, a 65,536 m2 island in SL was secured. Next, the learning environments were designed. All objects were 3D, and the environment included: (a) a virtual school building (Figures 1 and 2); (b) a canteen (Figure 3); (c) a garden (Figure 4); and (d) a contest area (Figure 5). Finally, the overall environment was checked by the researchers and any necessary corrections were made by the designer.

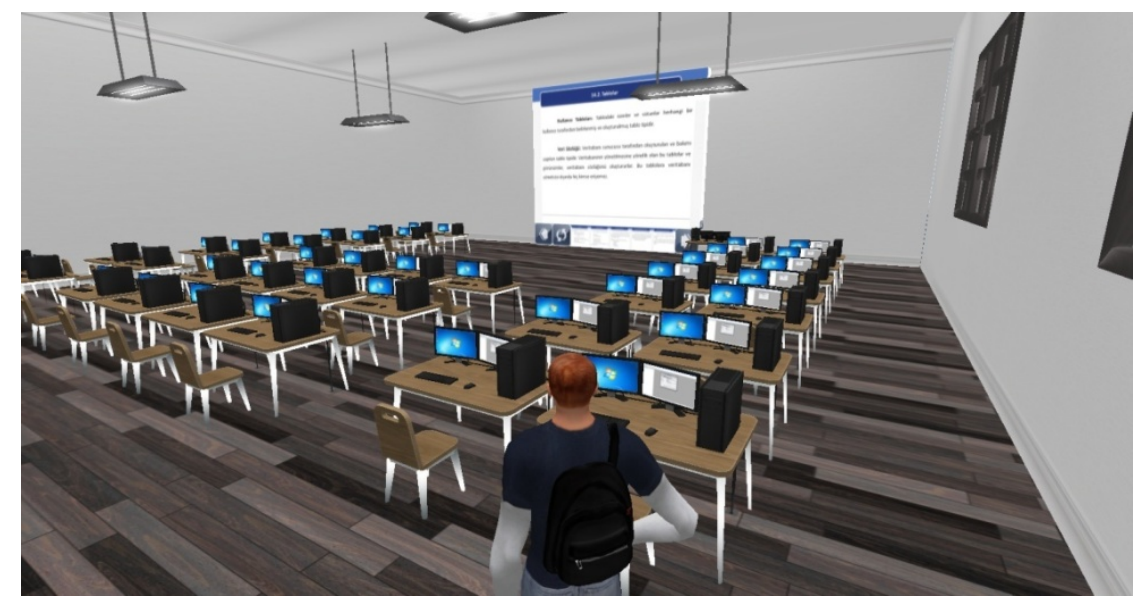

Figure 1. Lab on SL environment

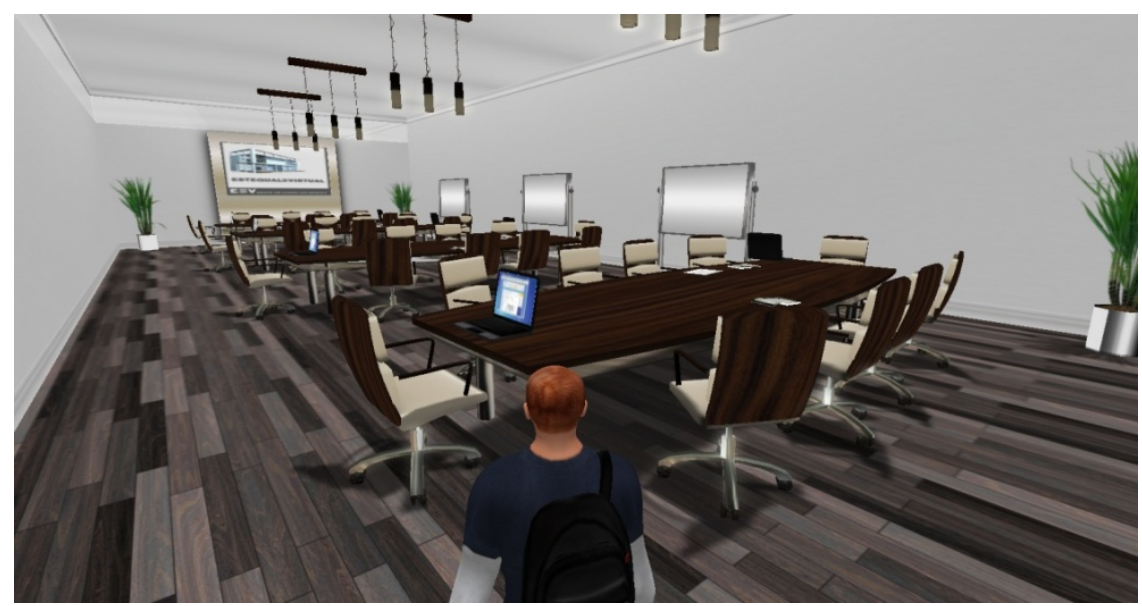

Figure 2. Group work room on SL environment 


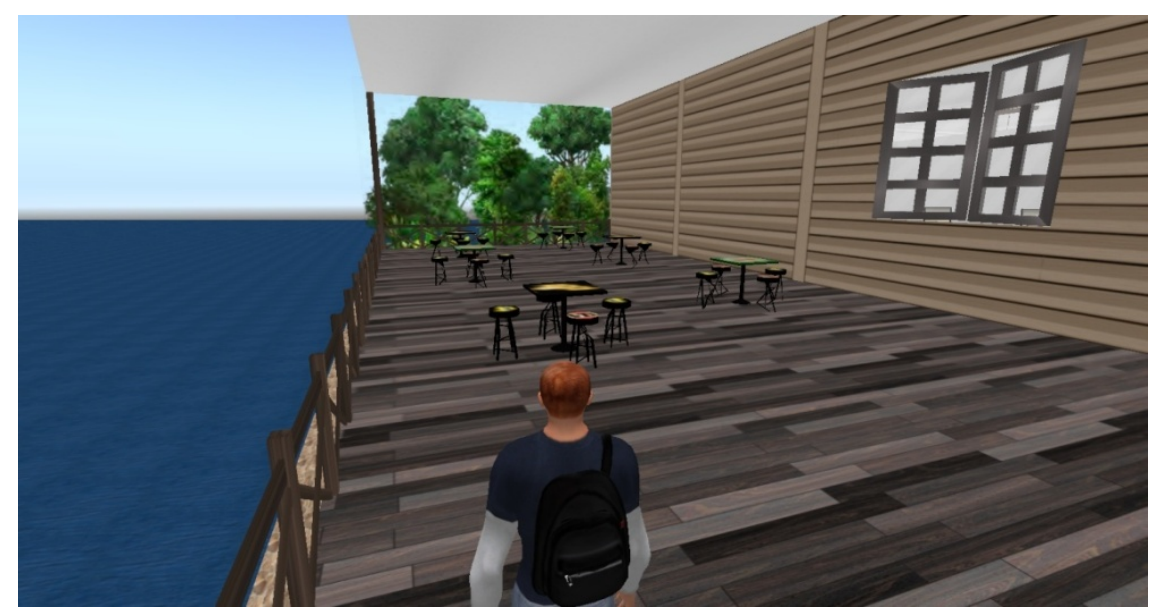

Figure 3. Canteen on SL environment

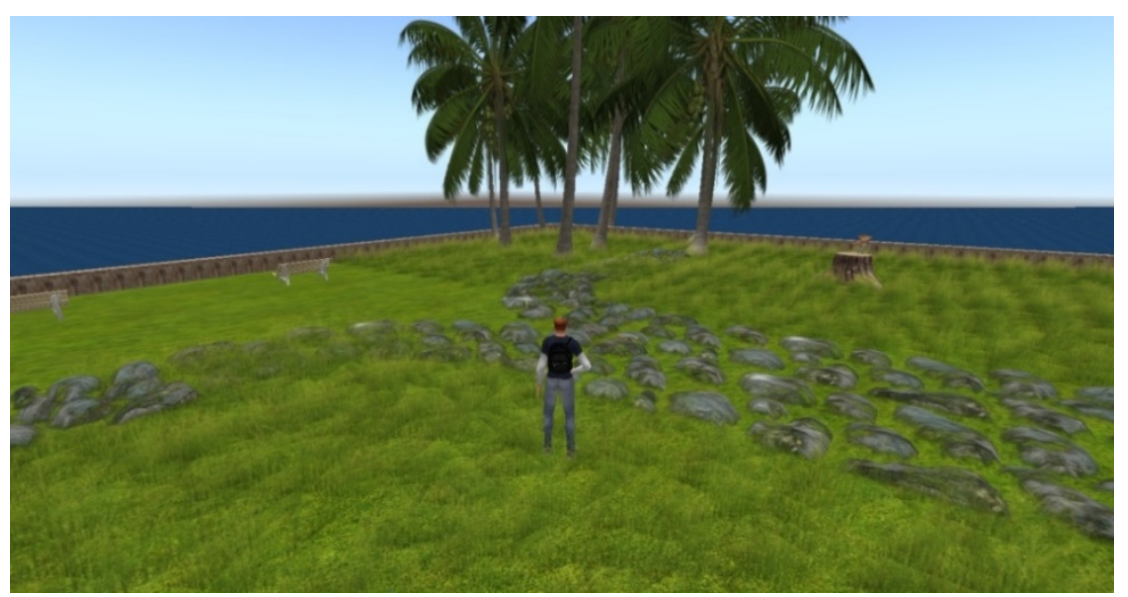

Figure 4. Garden on SL environment

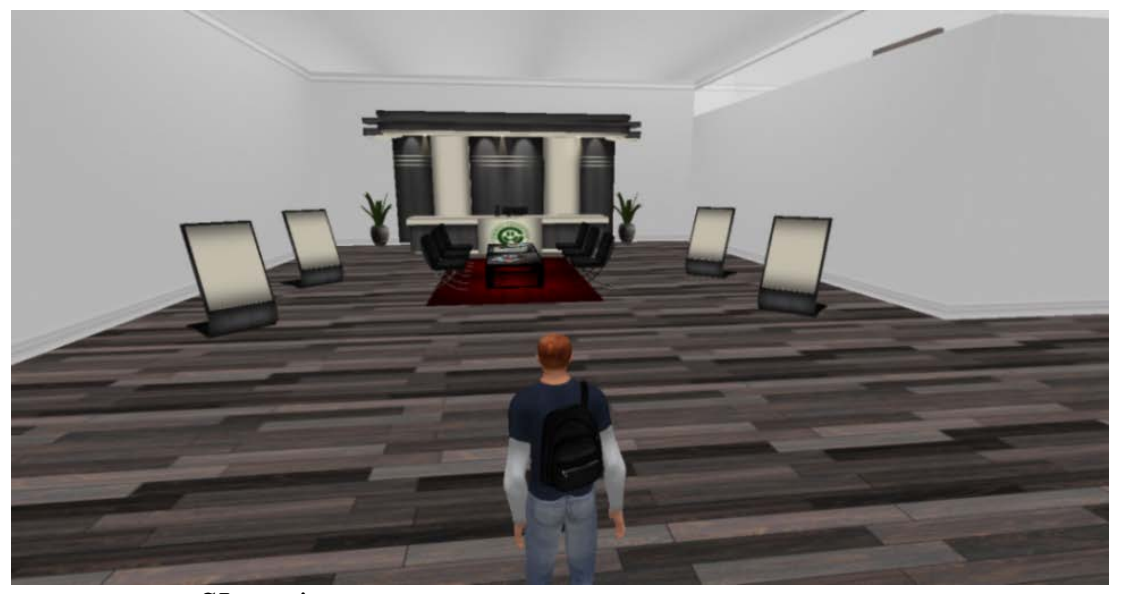

Figure 5. Contest room on SL environment

The second learning environment, made by Enocta, an LMS that helps institutions manage their educational and development projects by assessing whether they continue in accordance of defined goals. The Enocta LMS can be used for face-to-face education, e-learning, or blended learning. (Figures 6 \& 7) 


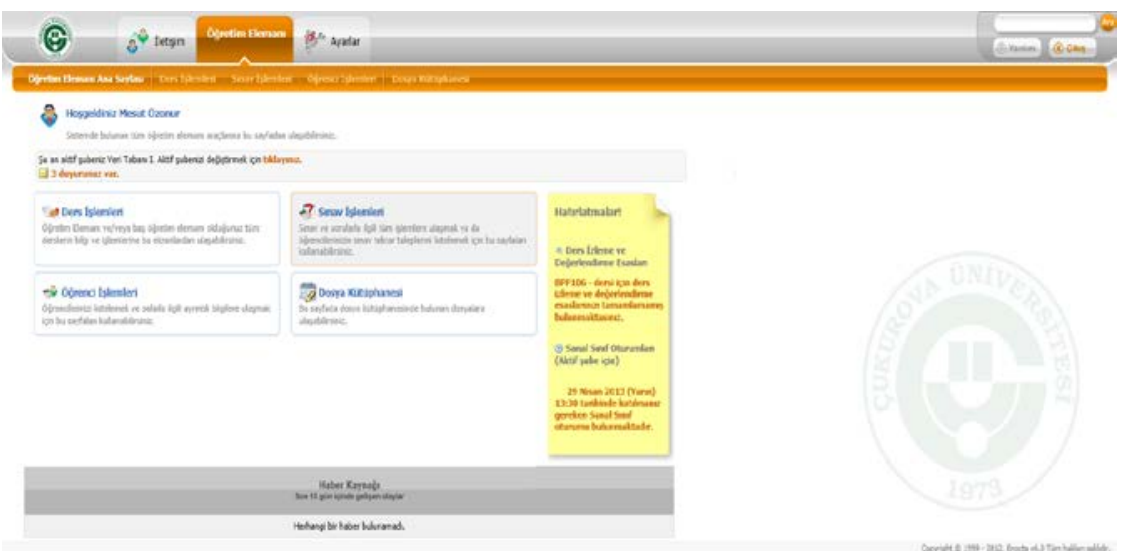

Figure 6. A screenshot of Enocta LMS

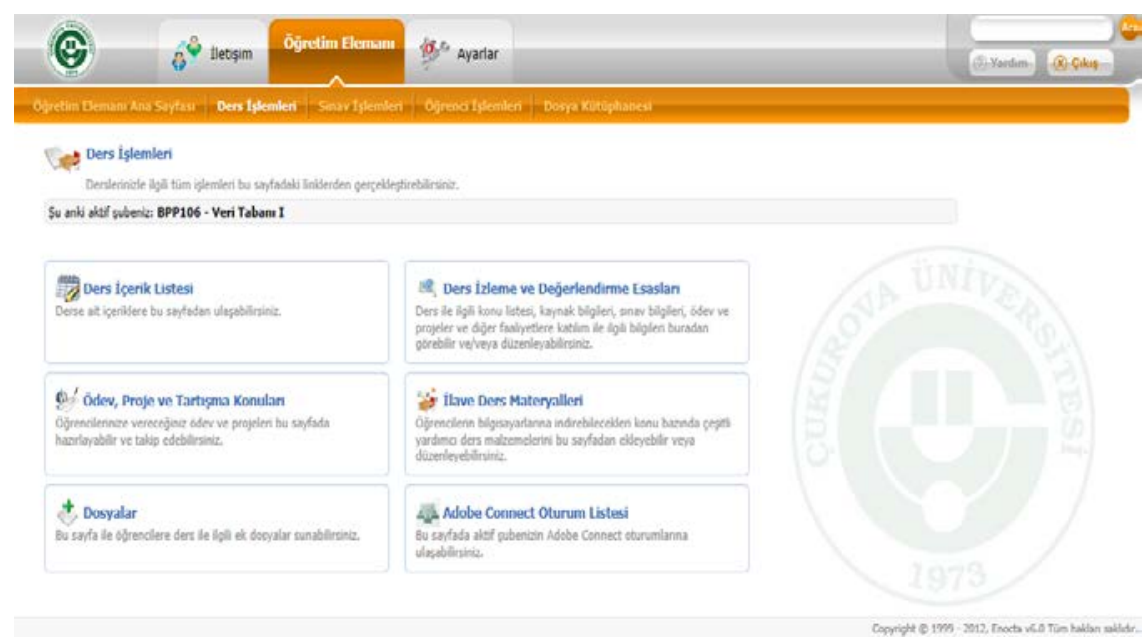

Figure 7. A screenshot of Enocta LMS

Adobe Connect is a platform developed for virtual meetings and content presentation and publication by Adobe Systems Incorporated. Adobe Connect is also used by educational institutions to offer online synchronous and asynchronous courses. Adobe has three main modules: meeting, presenter, and training. During the current study, the instructor used all modules. The instructors uploaded a PowerPoint for each week's topic using the meeting module and synchronously presented the content. All students in the control group entered the course at the same time, and during instruction, they could ask the instructor questions.

Post-tests

The instruments that were applied as pre-tests, the Sociability Scale and MSLQ, were also applied as posttests. These instruments were used to compare differences in the social presence and motivation pre- and post-test scores of the experimental and control groups.

\section{Data analysis}

SPSS 17.0 was used to analyse the data collected during the study. Independent $t$-test analysis was conducted, with dependent $t$-test (for within group comparisons) and independent $t$-test assumptions controlled (for between group comparisons), including extreme values, normality, and homogeneity of variances. For the social presence variable, there were no extreme values in the post-test score distribution. However, Kolmogorov-Smirnov test results showed that normality assumptions were violated in the experimental group post-test scores. For that reason, the Mann-Whitney $U$ test (a nonparametric alternative to the independent $t$-test) and Wilcoxon test (a nonparametric test alternative to the dependent $t$-test) were also conducted.

Similarly, extreme values were not found for the motivation variable. Moreover, normality assumptions were not violated according to Kolmogorov-Smirnov test results. As suggested by Buyukozturk (2002), 
homogeneity of variances was controlled through Box's $M$ statistics, which test equality of variance among individual variables. Since the result showed that the homogeneity assumption was violated, non-parametric tests were used: the Mann-Whitney $U$ and Wilcoxon tests.

\section{Validity issues}

Fraenkel and Wallen (2000) have identified many threats to experimental studies, as well as corresponding coping strategies. Threats such as participants' demographic characteristics (age, gender, etc.), instrument decay, data collector bias, testing time, implementation methods, and mortality consequences may affect the validity of matching-only pre- and post-test control group designs. Since participants were assigned to the experimental group according to academic success, gender, and age, participant characteristics were not a threat for this study. Moreover, the instruments used were valid and reliable. Instrument decay was not a validity problem in the current study. Data collector bias is related to a change in data collectors, which was avoided in the present study by using the same collector throughout. Experimental design, course design, and data analysis and interpretation were conducted after considering opinions from experts in instructional technology, educational sciences, and evaluation and measurement in education. A testing threat indicates the effects of pre-tests on post-test scores, which occurs when the time between the pre-test and post-test is too short. Since there were 14 weeks between applications, test threat was not considered a problem. Moreover, implementation was not a problem since the same instruction was provided by the same instructor for both the experimental and control groups.

\section{Ethical issues}

Before the study, permissions were collected from the institution where the data was gathered. Moreover, all instruments and procedures were controlled and checked by the ethics committee. At the beginning of the study, all participants signed a voluntary participation form. This experimental study included no harmful applications for the students, and each participant was provided with the same information during the treatment, by the same instructor. Since one of the researchers was also the instructor of the course, the data was not analysed until the course ended.

\section{Results}

In this part, the results are presented through statistical analysis conducted from three points of view:

1. The difference between the experimental group's pre- and post-test scores.

2. The difference between the control group's pre- and post-test scores.

3. The difference between gain scores of the experimental and control groups (ie., improvement from pre-test to post-test; Gain = post-test - pre-test).

Table 4 shows the mean and standard deviations of pre- and post-test scores from both groups. In terms of social presence, the experimental group pre-test mean score was 29.2 with a 6.68 standard deviation; the control group pre-test mean score was 32.7 with a 6.86 standard deviation. The experimental group posttest mean score increased significantly to 42.13 with a 7.57 standard deviation; the control group post-test mean score showed a small increase to 34.07 with a 5.89 standard deviation. In terms of motivation, the pre-test means of the scores of both groups were very close (154.47 with 16.51 standard deviation for the experimental group and 155.9 with 17.55 standard deviation for the control group). Again, the experimental group post-test mean score increased significantly to 172.07 with a 23.57 standard deviation, while the control group post-test mean score showed a decrease, to 150.5 with a 22.8 standard deviation.

Table 4

Experimental and control group mean and standard deviation scores from pre-tests and post-tests

\begin{tabular}{lccccc}
\hline Groups & & \multicolumn{2}{c}{ Experimental } & \multicolumn{2}{c}{ Control } \\
\cline { 3 - 6 } & & $M$ & $S D$ & $M$ & $S D$ \\
\hline Social Presence & Pre-test & 29,2000 & 6,68194 & 32,7000 & 6,86395 \\
& Post-test & 42,1333 & 7,56914 & 34,0667 & 5,88940 \\
\hline Motivation & Pre-test & 154,4667 & 16,50858 & 155,9000 & 17,55455 \\
& Post-test & 172,0667 & 23,56932 & 150,5000 & 22,80011 \\
\hline
\end{tabular}




\section{Experimental pre-test and post-test scores}

Social presence

Since the normality assumption of the dependent $t$-test was violated [Dpre-test(30) $=.115, p>.05$ and Dpost-test(30) $=.246, p<.05$ ], a Wilcoxon test was applied to analyse the difference between the experimental group pre- and post-test scores in terms of social presence. Wilcoxon test results showed a significant difference in favour of the post-test $(Z=-4.799, p<.05)$.

\section{Motivation}

Since assumptions were not violated [normality Dpre-test $(30)=.113, p>.05$ and Dpost-test(30) $=.150, p$ $>$.05], extreme values, and homogeneity of variances), a dependent $t$-test was applied to analyse the difference between experimental group pre- and post-test scores in terms of motivation. According to the results, a significant difference was found in favour of the post-test [t(29) $=-9.897, p<.05]$.

\section{Control group pre-test and post-test scores}

\section{Social presence}

Since normality assumptions were not violated [normality Dpre-test(30) $=.134, p>.05$ and Dpost-test(30) $=.130, p>.05]$, extreme values, and homogeneity of variances), a dependent $t$-test was applied to analyse control group pre- and post-test scores in terms of social presence. The results showed no significant differences $[t(29)=-1.360, p>.05]$.

\section{Motivation}

Since dependent $t$-test assumptions were not violated (normality [Dpre-test(30) $=.095, p>.05$ and Dposttest(30) $=.129, p>.05$ ], extreme values, and homogeneity of variances), a dependent $t$-test was applied to analyse control group pre- and post-test scores in terms of motivation. Analysis revealed no significant difference $[t(29)=1.595, p>.05]$.

\section{Gain scores of experimental and control group}

\section{Social presence}

Since the normality assumption was violated [Dcontrol(30) $=.202, p<.05$ and Dexperimental(30) $=.200$, $p<.05$ ], a Mann-Whitney $U$ test was applied instead of an independent $t$-test to analyse the difference between the social presence gain scores of the control and experimental groups. Analysis found a significant difference $(U=.000, p<.05)$.

\section{Motivation}

Since the independent $t$-test normality assumption was violated [Dcontol(28) $=.946, p>.05$ and Dexperimental $(28)=.920, \mathrm{p}<.05]$, a Mann-Whitney $U$ test was applied to analyse the difference between the motivation gain scores of the control and experimental groups. Analysis found a statistically significant difference between gain scores of control and experimental groups $(U=9.000, p<.05)$.

In sum, the results of the statistical analysis showed that the experimental group, who took the Database II course through SL, had higher levels of social presence and motivation than the control group, who took the Database II course using the Enocta LMS/Adobe Connect.

\section{Discussion and conclusion}

This study was concerned with the effects of learning environment (SL versus the Enocta LMS/Adobe Connect) on students' social presence and motivation. Compared to pre-test mean scores, in terms of social presence, the experimental group post-test mean score increased significantly (Mexperimental post-test social presence $=42.13$ ), while the control group post-test mean score showed a small increase (Mcontrol post-test social presence $=34.07)$. Mann-Whitney $U$ test results showed a significant difference in favour of the experimental group in terms of social presence gain scores $(U=.000, p<.05)$. Streur (1992) emphasised that social presence is the key feature of virtual worlds. Moreover, Bulu (2011) found that the most important variable affecting student satisfaction in SL learning environments was social presence. Omale et al.'s (2009) study results also showed that the 3D environment and speech bubbles caused an 
increase in participants' social presence. Bowers (2010), Collins (2012), Khan (2011), Macedo and Morgado (2009), Omale (2010), Palomaki (2009), and Zhang (2009) all found that learning environments like SL offer opportunities for social presence that increase collaboration, dialogue, and interaction between participants.

Other studies reveal findings which indicate that 3D virtual learning environments offer the chance for participants to be sincere with counterparts, to be active and social, and to feel companionship, while being suitable for all participants and capturing their attention (Çukurbaşı, 2012; Küfrevioğlu, Topu, Çoban, \& Göktaş, 2012). All these studies support virtual learning environments, such as SL, as providing communication and interaction between participants. Another reason for the significant difference in favour of the experimental group students' social presence scores in the current study may stem from disadvantages of web-based education as stated by Olpak (2010): face-to-face instruction is limited in these environments, participants feel alone, and participants have anxiety about communicating with other participants and instructors.

In terms of motivation, the experimental group post-test mean scores increased significantly (Mexperimental post-test motivation $=172.07)$, while the control group post-test mean scores showed a small decrease (Mcontrol post-test motivation $=150.5)$. The Mann-Whitney $U$ test results showed a significant difference between motivation gain scores in favour of the experimental group $(U=9.000, p<$ .05). The comparison results of gain scores between the experimental and control group students indicate that the experimental group students' motivation levels were affected by the learning environment (SL). This study's findings show similarity with the findings of some other research studies conducted before. Jin's (2011) experimental study showed a significant interaction between message framing and students' motivational systems on their enjoyment of the e-learning experience in SL environments. Çukurbaşı et al. (2011) reported that students found an instruction session in SL entertaining and motivating. Similarly, Bezir (2012), Bulu and İşler (2011), Çukurbaşı (2012), and Doğan, Küfrevioğlu, Reisoğlu, and Göktaş (2011) found that SL learning environments enhance students' motivation and make learning attractive.

According to Coffman and Klinger's (2008) study, learning environments like SL motivate students by capturing their attention and providing them with opportunities to discover information. Wang and Shao (2012) and Kamalı (2012) used SL as a learning environment for second language classes and found it a successful motivator. Similarly, Wang and Braman (2009) found that educational activities applied through SL enhanced students' motivation. Ma et al. (2009) and Collins (2012) further concluded that virtual environments such as SL may be used as motivational tools. Many scholars have also pointed out that communication and interaction are two important factors for motivation. Lu et al., (2007) stated that social presence level is associated with student satisfaction as well as motivation during instructional and educational activities. Gülbahar (2009) and Olpak (2010) identified disadvantages of web-based instruction as inadequate social presence, feeling alone, insufficient multidirectional communication, and limited interaction; these disadvantages also affect motivation in a negative way. The reason for the significant increase in the motivation levels of the experimental group and the small decrease for the control group may stem from interactive, communicative, and attractive feelings about SL and the lack of those feelings about the Enocta LMS/Adobe Connect learning environments.

This study adds to the existing literature an empirical support about the effect of the properties of interactive learning environments on students' social presence and motivation. This study lacks an in-depth explanation into the reasons for the study results since qualitative data was not applied. For further study, qualitative data could be collected through interviews or open-ended questionnaires to gather more participant feedback. This study is still important for revealing how properties of learning environments may affect social presence and motivation. The number of participants in the current study could be regarded as a limitation. It is also important to note Salmon’s (2009) statement:

As with all learning technologies, it is the complex marriage of the technological application with the challenging pedagogical drivers that results in appropriate support and learning design. (p. 536)

For this reason, additional research studies are suggested to include different instructional design approaches such as problem based approach, project based approach, task-based approaches, and so on. Feedback procedures supported with a blog-forum could be designed for students taking courses through 
web-based instructional environments such as Adobe Connect. In these studies, researchers should investigate whether motivational and social presence levels increase based on instructional design. These additional studies would contribute further to the literature and the efforts of distance education practitioners to provide better opportunities for learners.

\section{Acknowledgements}

We thank Mersin University Scientific Research Project Unit for their support of our study under a research project (Project number: BAP-EBE EBEPÖB (MÖ) 2012-3 DR).

\section{References}

Ahl, H. (2006). Motivation in adult education: A problem solver or a euphemism for direction and control. International Journal of Lifelong Education, 25(4), 385-405.

Al, U., \& Madran, O. (2004). Web-tabanlı uzaktan eğitim sistemleri sahip olması gereken özellikler ve standartlar [Web-based distance education systems: Required features and standards]. Bilgi Dünyast [Information World], 5(2), 259-271.

Artino, A. R. (2005). Review of the motivated strategies for learning questionnaire. Retrieved from https://eric.ed.gov/?id=ED499083

Balcıkanl1, C. (2012). Language learning in Second Life: American and Turkish students' experiences. Turkish Online Journal of Distance Education, 13(2), 131-146.

Bardakçı, S. (2010). Çevrimiçi öğrenme ortamında algılanan sosyalleşme ölçeğinin geçerlik ve güvenirlik çalışması [The validity and reliability study of the scale of the perceived sociability of online learning environments]. Ankara Üniversitesi Eğitim Bilimleri Fakültesi Dergisi [Ankara University, Journal of Faculty of Educational Sciences], 43(1), 17-39.

Bell, D. (2009). Learning from Second Life. British Journal of Educational Technology, 40(3), 515-525. http://doi.org/10.1111/j.1467-8535.2009.00943.x

Bezir, Ç. (2012). Second Life ortamında tasarlanan yabancı dil ĕgitimi: Öğretmen-öğrenci ve ortam etkileşimi [Foreign language education in the Second Life: Student-teacher and context interaction]. (Master's thesis). Dokuz Eylül University, Izmir, Turkey.

Bowers, K. W. (2010). Constructing the new classroom: College student perceptions of classes using Second Life (Doctoral dissertation). University of Florida, FL, USA.

Bulu, S. T. (2011). Place presence, social presence, co-presence, and satisfaction in virtual worlds. Computers \& Education, 58(1), 154-161. http://doi.org/10.1016/j.compedu.2011.08.024

Bulu, S. T., \& İşler, V. (2011, February). Second Life ODTÜ kampüsü [Second Life METU Campus]. Paper presented at Akademik Bilişim’ 11 Conference, Malatya.

Büyüköztürk, Ş. (2002). Sosyal bilimler için veri analizi el kitabı [Data analysis handbook for social sciences]. Ankara: Pegem A Publishing.

Büyüköztürk, Ş., Akgün, Ö., Özkahveci, Ö., \& Demirel, F. (2004). Güdülenme ve öğrenme stratejileri ölçeğinin Türkçe formunun geçerlik ve güvenirlik çalışması [The validity and reliability study of the Turkish version of the motivated strategies for learning questionnaire]. Kuram ve Uygulamada Ĕgitim Bilimleri [Educational Sciences: Theory and Practice], 4(2), 207-239.

Coffman, T., \& Klinger, M. B. (2008). Utilizing virtual worlds in education: The implications for practice. International Journal of Social Sciences, 2(1), 29-33.

Collins, S. K. (2012). How e-learning with Second Life, an online virtual world technology system, affects teaching and learning (Doctoral dissertation). Walden University, MN.

Çukurbaşı, B. (2012). Üç boyutlu sanal ortamda beş aşamalı modelin uygulanması [Five stage model application in three dimensional virtual environments] (Master's thesis). Balıkesir University, Turkey.

Çukurbaşı, B., Bezir, Ç., \& Karamete, A. (2011, September). Üç boyutlu sanal ortamlarda oryantasyon [Orientation of three dimensional virtual environments]. Paper presented at the 5th International Computer and Instructional Technologies Symposium, Firat University, Elazig, Turkey.

Doğan, D., Küfrevioğlu, R., Reisoğlu, İ., \& Göktaş, Y. (2011, September). Sanal ortamların eğitim amaçlı kullanılabilirliğinin değgerlendirilmesi [Evaluation of training for usability of virtual environments]. Paper presented at the 5th International Computer \&Instructional Technologies Symposium, Firat University, Elazig, Turkey. 
Edirisingha, P., Nie, M., Pluciennik, M., \& Young, R. (2009). Socialisation for learning at a distance in a 3-d multi-user virtual environment. British Journal of Educational Technology, 40(3), 458-479. http://dx.doi.org/10.1111/j.1467-8535.2009.00962.x

Fraenkel, J. R., \& Wallen, N.E. (2000). How to design and evaluate research in education. Boston: McGraw-Hill.

Garrison, D. R. (2007). Online community of inquiry review: Social, cognitive, and teaching presence issues. The Sloan Consortium, 11(1), 61-72.

Gülbahar, Y. (2009). E-öğrenme [E-learning]. Ankara: Pegem Akademi Publishing.

Hannum, W. (2008). Distance learning. In R. B. Diamond (Editor), Designing and assessing courses and curricula: A practical guide (pp. 237-256). San Francisco, CA: Jossey-Bass.

Jin, S. A. A. (2011). Leveraging avatars in 3D virtual environments (Second Life) for interactive learning: The moderating role of the behavioral activation system vs. behavioral inhibition system and the mediating role of enjoyment. Interactive Learning Environments, 19(5), 467-486. https://doi.org/10.1080/10494820903484692

Kamal1, T. (2012). Effects of second life environment on preparatory class students' attitude, selfconfidence, motivation towards English speaking: The case of Middle East Technical University (Master's thesis). Middle East Technical University, Ankara, Turkey.

Karaş, İ. R, \& Kahraman, İ. (2011, April). Uzaktan ĕgitim yöntemi ile coğrafi bilgi sistemi öğrenimi [Geographic information systems education by using distance learning method]. Paper presented at 13. Türkiye Harita Bilimsel ve Teknik Kurultayı [13. Turkey Map Science and Technic Congress], Ankara, Turkey.

Keegan, D. (1980). On defining distance education. Distance Education, 1(1), 13-36. https://doi.org/10.1080/0158791800010102

Keskitalo, T., Pyykkö, E., \& Ruokamo, H. (2011). Exploring the meaningful learning of students in Second Life. Educational Technology \& Society, 14(1), 16-26.

Khan, S. (2011). Sarah \& Emma: Case studies of two instructors and how they use social presence in Second Life (Doctoral dissertation). Texas State University, TX.

Kreijns, K., Kirschner, P. A., Jochems, W., \& Van Buuren, H. (2007). Measuring perceived sociability of computer-supported collaborative learning environments. Computers \& Education, 49(2), 176-192. http://doi.org/10.1016/j.compedu.2005.05.004

Küfrevioğlu, R. M., Topu, F. B., Çoban, M., \& Göktaş, Y. (2012, May). 3 boyutlu sanal dünyalarda buradalı ve sosyal buradalı [Presence and social presence on 3 Dimensional Virtual Worlds]. Paper presented at 4. Eğitim Araştırmaları Birliği Kongresi [4. Educational Researchers Community Conference], Yıldız Technical University, İstanbul, Turkey. Retrieved from http://www.muratcoban.com/yayin/istanbul.pdf

Lou, Y. (2004). Learning to solve complex problems through between-group collaboration in projectbased online courses. Distance Education, 25(1), 49-66.

Lu, Y., Huang, W., Ma, H., \& Luce, T. (2007, September). Interaction, social presence in technology mediated learning - A partial least square model. Paper presented at International Conference on Communication, Networking, Mobile Computing, WiCOM Management Track: Information Systems \& Management, China.

Ma, M., Oikonomou, A., \& Zheng, H. (2009, November). Second Life as a learning and teaching environment for digital games education. Paper presented at the 12th Annual International Workshop on Presence (PRESENCE 2009), Los Angeles, CA.

Macedo, A., \& Morgado, L. (2009, October). Learning to teach in Second Life. Paper presented at the EDEN Open Classroom Conference, Portugal.

Mayrath, M. C., Traphagan, T., Heikes, E. J., \& Trivedi, A. (2011). Instructional design best practices for Second Life: A case study from a college-level English course. Interactive Learning Environments, 19(2), 125-142. https://doi.org/10.1080/10494820802602568

Mennecke, B. E., McNeill, D., Ganis, M., Roche, E. M., Bray, D. A., Konsynski, B., Townsend, A. M., \& Lester, J. (2008). Second Life and other virtual worlds: A roadmap for research. Communications of The Association for Information Systems, 22(20), 371-388.

Odabaş, H. (2003). İnternet tabanlı uzaktan eğitim ve bilgi ve belge yönetimi bölümleri [Internet based distance education and departments of information and records management]. Türk Kütüphaneciliği [Turkish Librarianship], 17(1), 22-36.

Olpak, Y. Z. (2010). Çevrimiçi öğrenme ortamlarında kullanılan farklı etkileşim araçlarının öğrencilerin başarlarına ve sosyal bulunuşluk algılarına etkisi [Effects of different interaction tools used in online 
learning environments to the achievements and social presence perceptions of students] (Master's thesis). Gazi University, Ankara, Turkey.

Omale, N. M. (2010). Exploring the use of 3-D multi-user virtual environments for online problem-based learning (Doctoral dissertation). Northern Illinois University, IL.

Omale, N. M., Hung, W.-C., Luetkehans, L., \& Cooke-Plagwitz, J. (2009). Learning in 3-D multiuser virtual environments: Exploring the use of unique 3-D attributes for online problem-based learning. British Journal of Educational Technology, 40(3), 480-495. https://doi.org/10.1111/j.14678535.2009.00941.x

Özkul, A. E., \& Aydın, C. H. (2013). Açık ve uzaktan öğrenmenin temelleri ve araştırmaları [Origin and research of open and distance learning ]. In K. Çağıltay, \& Y. Göktaş (Eds.), Öğretim teknolojisinin temelleri: Teoriler, araştırmalar, eğilimler [The roots of Instructional Technology: Theories, researchers,trends] (pp. 557-570). Ankara: Pegem Publication.

Palomaki, E. (2009). Applying 3D virtual worlds to higher education (Master's thesis). Helsinki University of Technology, Finland.

Salmon, G. (2009). The future for (second) life and learning. British Journal of Educational Technology, 40(3), 526-538. https://doi.org/10.1111/j.1467-8535.2009.00967.x

Sancar Tokmak, H., Baturay, M., \& Fadde, P. (2013). Applying the context, input, process, product evaluation model for evaluation, research, and redesign of an online master's program. The International Review of Research in Open and Distance Learning, 14(3), 273-293.

Steuer, J. (1992). Defining virtual reality: Dimensions determining telepresence. Journal of Communication, 42(4), 73-93.

Vrellis, I., Avouris, N., \& Mikropoulos, T.A. (2016). Learning outcome, presence and satisfaction from a science activity in Second Life. Australasian Journal of Educational Technology, 32(1), 59-77. https://doi.org/10.14742/ajet.2164

Wang, Y., \& Braman, J. (2009). Extending the classroom through Second Life. Journal of Information Systems Education, 20(2), 235-247.

Wang, F., \& Shao, E. (2012). Using Second Life to assist EFL teaching: We do not have to sign in to the program. TechTrends, 56(4), 15-18. https://doi.org/10.1007/s11528-012-0582-4

Warburton, S. (2009). Second Life in higher education: Assessing the potential for and the barriers to deploying virtual worlds in learning and teaching. British Journal of Educational Technology, 40(3), 414-426. https://doi.org/10.1111/j.1467-8535.2009.00952.x

Willging, P. A., \& Johnson, S. D. (2004). Factors that influence students' decision to dropout of online courses. Journal of Asynchronous Learning Networks, 8(4), 105-118.

Zhang, C. (2009). Understanding the impact of virtual world environments on social and cognitive processes in learning (Doctoral dissertation). University of Nebraska, NE.

Corresponding author: Hatice Sancar Tokmak, hsancartokmak@mersin.edu.tr

Australasian Journal of Educational Technology (c) 2018.

Please cite as: Ozonur, M., Yanpar-Yelken, T., \& Sancar-Tokmak, H. (2018). Social presence and motivation in online environments: Second Life versus the Enocta Learning ManagementSystem/Adobe Connect. Australasian Journal of Educational Technology, 34(3), 1-14. https://doi.org/10.14742/ajet.3128 